\title{
Volatile organic compound removal over bentonite- supported Pt, Mn and Pt/Mn monolithic catalysts
}

\author{
J. Esteban Colman-Lerner • Miguel A. Peluso • \\ Jorge E. Sambeth $\cdot$ Horacio J. Thomas
}

Received: 24 August 2012/ Accepted: 19 November 2012/Published online: 9 December 2012 (C) Akadémiai Kiadó, Budapest, Hungary 2012

\begin{abstract}
The catalytic oxidation of volatile organic compounds (VOCs) (ethanol and toluene) alone and in mixture was investigated over $\mathrm{Pt}, \mathrm{Mn}$ and $\mathrm{Pt} / \mathrm{Mn}$ impregnated bentonite monoliths. Their properties were characterized by using the Brunauer-Emmett-Teller method, X-ray diffraction, X-ray photoelectron spectra and temperature programmed reduction (TPR). Independently of which catalyst was used, ethanol was more easily oxidized than toluene. In toluene oxidation, the sequence of catalytic activity was as follows: $\mathrm{Pt} / \mathrm{Mn} / \mathrm{B}>\mathrm{Pt} / \mathrm{B}>\mathrm{Mn} / \mathrm{B}$, probably due to some favorable synergetic effects between $\mathrm{Pt}$ and $\mathrm{Mn}$ and to the presence of $\mathrm{Mn}^{3+} / \mathrm{Mn}^{4+}$ species. In ethanol oxidation, $\mathrm{Pt} / \mathrm{Mn} / \mathrm{B}$ and $\mathrm{Pt} / \mathrm{B}$ present similar activities, and greater than that of $\mathrm{Mn} / \mathrm{B}$. In the VOC mixture, toluene slows down the partial oxidation of ethanol towards acetaldehyde. On the contrary, the presence of ethanol has a promoting effect on toluene oxidation.
\end{abstract}

Keywords Bentonite $\cdot$ VOCs mixtures $\cdot \mathrm{MnO}_{x} \cdot \mathrm{Pt}$

J. E. Colman-Lerner · M. A. Peluso $(\bowtie) \cdot$ J. E. Sambeth · H. J. Thomas

Centro de Investigación y Desarrollo en Ciencias Aplicadas "Dr. Jorge J. Ronco", CONICET CCT

La Plata, UNLP, $47 \mathrm{~N}^{\circ}$ 257, 1900 La Plata, Argentina

e-mail: apelu@quimica.unlp.edu.ar

J. E. Colman-Lerner · M. A. Peluso · J. E. Sambeth

Facultad de Ciencias Exactas, UNLP, 47 and 115, 1900 La Plata, Argentina

J. E. Colman-Lerner

Centro de Investigaciones del Medio Ambiente (CIMA), Facultad de Ciencias Exactas, UNLP,

47 y 115, 1900 La Plata, Argentina

H. J. Thomas

Planta Piloto Multipropósito PLAPIMU, CICPBA-UNLP, C. Centenario and 506,

M. B. Gonnet, Argentina 


\section{Introduction}

Volatile organic compounds (VOCs) are considered as significant atmospheric pollutants not only for their toxicity and malodorous nature, but also because they are ozone and smog precursors [1]. Catalytic oxidation can be considered an effective way for reducing the emissions of VOCs from stationary sources [2-4]. Supported platinum and palladium are the most commonly used catalysts $[5,6]$. Nevertheless, the development of transition metal oxides for catalytic combustion has been widely reported in the literature [7-10], because they are cheaper than noble metals.

For practical applications regarding VOC oxidation, the catalyst should be supported on a structured support to treat large gas flows with low pressure drop. The most widely used structured supports are the honeycomb monoliths made of ceramic or metallic materials [11].

Manganese oxide and platinum supported on metallic or ceramic monoliths are widely employed in the combustion of single VOCs [12-15].

In practical applications (for example, contaminated air treatment in solvent evaporation processes) the gas streams contain mixtures of VOCs of variable composition. It has been reported that the oxidation of a VOC in a mixture differs from its single oxidation due to the interaction of the different species with the catalyst. Santos et al. [16] observed mutual inhibitory effects between ethanol and toluene over $\mathrm{TiO}_{2}$-supported noble metal catalysts. Tsou et al. [17] studied the oxidation of $o$-xylene and methyl-isobutyl-ketone over Pt-catalysts, observing an inhibitory effect of $o$-xylene on methyl-isobutyl-ketone, due to a competition on the active sites. Kim and Shim [18] observed a mutual inhibitory effect between toluene and benzene over a $\mathrm{Ca} / \mathrm{Mn}_{3} \mathrm{O}_{4}$ catalyst. They suggest that the reaction was a competitive one running on the same active sites. On the other hand, a promoting effect could be due to the exothermic character of the complete oxidation reaction, which locally raises the surface temperature of the catalyst [19].

The rheological properties of clays and clay minerals are ideal raw materials for preparing structured supports and catalysts [20-22] being a better alternative to metallic ones. However, most of the work performed in ceramic monoliths deals with the ceramic called "cordierite" [23, 24]. Nevertheless, the processing of cordierite is high energy demand. The abundance of natural clay and its low cost are likely to make it a strong candidate as catalysts support. A series of bentonite resources are located in Northern Patagonia, Argentina. These resources extend over an area of $94,000 \mathrm{~km}^{2}$ and constitute $80 \%$ of the country's yearly production of bentonites. Reserve estimation is about 3,500,000 tons. They are mainly sodium bentonites and mixtures $\mathrm{Na} / \mathrm{Ca}[25]$.

The aim of this work is to study the catalytic behavior of a catalyst based on a manganese oxide or platinum supported on bentonite based monoliths in the combustion of two VOCs (ethanol and toluene) generally found in emissions of the printing industries $[26,27]$. The catalytic performance in the oxidation of the VOCs separately and in binary mixture was evaluated. 


\section{Experimental}

\section{Monoliths preparation}

A natural bentonite (90 wt $\%$ montmorillonite) from North Patagonia, Argentina, was used. Its percent chemical composition, given by the supplier was $\mathrm{SiO}_{2}$ : 58.0, $\mathrm{Al}_{2} \mathrm{O}_{3}$ : 20.1, MgO: 2.66, $\mathrm{CaO}: 0.77, \mathrm{Fe}_{2} \mathrm{O}_{3}$ : 5.88, $\mathrm{Na}_{2} \mathrm{O}: 2.28, \mathrm{~K}_{2} \mathrm{O}: 0.01, \mathrm{TiO}_{2}$ : 0.55, MnO: 0.01 and 8.0 of undetermined ashes (mass contents for the dry sample).

A clay (Tincar Super, Piedra Grande, Argentine) and gibbsite, $\mathrm{Al}(\mathrm{OH})_{3}$ (Alcan) were aggregated to the bentonite.

Extrusion of bentonite dough was performed on a UNICERAM Groupe Mirovide studer, with a water content of $8 \mathrm{wt} \%$. The paste was dried $48 \mathrm{~h}$ at room temperature and finally heated at $800{ }^{\circ} \mathrm{C}$ for $2 \mathrm{~h}$ in an electric furnace in air atmosphere.

The characteristics of the elaborated monoliths were: Shape of cells: triangular, Cell density: 3.1 cells $\mathrm{cm}^{-2}$; Cell dimension: $0.2 \mathrm{~cm}^{2}(0.4 \times 0.5)$; Wall thickness: $0.15 \mathrm{~cm}$; Catalyst block dimension: $1.8 \mathrm{~cm}$ diameter, $2 \mathrm{~cm}$ high; Open area: $1.4 \mathrm{~cm}^{2}$.

\section{Catalyst preparation}

The preparation of supported catalysts was carried out as follows:

$P t / B$ Bentonite monoliths were immersed in an aqueous solution of $\mathrm{H}_{2} \mathrm{PtCl}_{6} \cdot \mathrm{H}_{2} \mathrm{O}$ $0.02 \mathrm{M}$, inside a closed vessel and put through to mechanical orbital agitation for $60 \mathrm{~min}$. Subsequently, the monoliths were washed with deionized water to remove chloride, dried overnight at $100{ }^{\circ} \mathrm{C}$, and calcined at $500{ }^{\circ} \mathrm{C}$ for $2 \mathrm{~h}$.

$M n / B$ The impregnation of the monoliths was carried out in two stages according to Ref. [28]: first, the monoliths were immersed in $100 \mathrm{ml}$ of a $1 \mathrm{M}$ aqueous solution of $\mathrm{Mn}\left(\mathrm{NO}_{3}\right)_{2}$ and kept under agitation for $60 \mathrm{~min}$. Then monoliths were dried at $100{ }^{\circ} \mathrm{C}$ for $4 \mathrm{~h}$. After this stage, monoliths were immersed in a $0.66 \mathrm{M}$ aqueous solution of $\mathrm{KMnO}_{4}$. After agitation for $60 \mathrm{~min}$, the impregnated monoliths were dried at $100{ }^{\circ} \mathrm{C}$ for $4 \mathrm{~h}$ and finally calcined at $500{ }^{\circ} \mathrm{C}$ for $2 \mathrm{~h}$.

$\mathrm{Pt} / \mathrm{Mn} / \mathrm{B} \mathrm{Mn} / \mathrm{B}$ monoliths, after having been calcined at $500{ }^{\circ} \mathrm{C}$, were impregnated with $\mathrm{H}_{2} \mathrm{PtCl}_{6} \cdot \mathrm{H}_{2} \mathrm{O} 0.02 \mathrm{M}$ in the same way as the $\mathrm{Pt} / \mathrm{B}$ monoliths. After impregnation, the monoliths were dried overnight at $100{ }^{\circ} \mathrm{C}$ and calcined at $500{ }^{\circ} \mathrm{C}$ for $2 \mathrm{~h}$.

\section{Catalyst characterization}

Manganese and platinum contents were measured by atomic absorption spectroscopy with a Varian AA 240 instrument after dissolving previously crushed and milling monoliths with $\mathrm{HF}-\mathrm{HNO}_{3}-\mathrm{HCl}$ mixture.

The Brunauer-Emmett-Teller (BET) surface areas, total pore volume, and average pore diameter of the samples were measured by $\mathrm{N}_{2}$ adsorption at liquid 
nitrogen temperature $(77 \mathrm{~K})$ in a Micromeritics ASAP 2000 sorptometer. The experiments were performed over small pieces of crushed monoliths.

The surface morphology of the monoliths was studied by scanning electron microscopy (SEM) using a Philips SEM 505 microscope. The experiments were performed over small pieces of crushed monoliths.

The samples were characterized by X-ray diffraction (XRD) methods using a Philips diffractometer in powder form (previously ground monolith). The diffraction patterns were recorded at room temperature from $5^{\circ}$ to $70^{\circ}$ of $2 \theta$ using $\mathrm{Cu} \mathrm{K}$ $\left(\lambda=1.5406 \AA\right.$ ) radiation at $0.02 \mathrm{~min}^{-1}$ scanning speed and a counting time of $2 \mathrm{~s}$ per step.

X-ray photoelectron spectra (XPS) of the compounds in powder form (previously ground monolith) were obtained using a multitechnique system, with a Mg X-ray source and a hemispherical PHOIBOS 150 analyzer operating in the fixed analyzer transmission mode. Binding energies (BE: $\pm 0.1 \mathrm{eV}$ ) were calculated using adventitious hydrocarbon $(\mathrm{C} 1 \mathrm{~s}=284.6 \mathrm{eV})$ as the internal reference. Curve fitting was performed with the CasaXPS software.

Temperature programmed reduction (TPR) experiments were performed in Quantachrome equipment Quantasorb Jr., using 25-50 mg of sample in powder form (previously ground monolith). In all cases, the temperature was increased from ambient to $900{ }^{\circ} \mathrm{C}$ at a heating rate of $10{ }^{\circ} \mathrm{C} \min ^{-1}$. A gas mixture of $\mathrm{H}_{2}-\mathrm{N}_{2}, 5 \%$ by volume was used as reducing gas, at a total flow rate of $22 \mathrm{~cm}^{3} \mathrm{~min}^{-1}$. Copper oxide was used for the calibration of the equipment. Quantification of the TPR results was performed assuming that at the end of the experiments all $\mathrm{Mn}$ is as $\mathrm{MnO}$.

The acidity of the samples was measured in a Metrohm 794 Basic Titrino with interchanged unity 806 and a Metrohm electrode. A representative $0.50 \mathrm{~g}$ sample in powder form was suspended in $45 \mathrm{ml}$ of acetonitrile solution and allowed $3 \mathrm{~h}$ in agitation to come to stabilization. This suspension was then titrated with $0.025 \mathrm{~N}$ $n$-butylamine solution.

The adherence of the coatings was evaluated in terms of the weight loss after exposure of the monoliths to ultrasounds. The impregnated monoliths were immersed in $25 \mathrm{ml}$ petroleum ether, inside a sealed beaker, and then treated in an ultrasound bath for $30 \mathrm{~min}$, in a TESTLAB TB10 at $400 \mathrm{~W}$ and $40 \mathrm{kHz}$. After that, the monoliths were dried at $100{ }^{\circ} \mathrm{C}$ for $2 \mathrm{~h}$. The weight loss (in wt $\%$ ) was determined by measuring the weight of the samples both before and after the ultrasonic treatment.

\section{Catalytic oxidation}

The catalytic activity of the prepared monoliths was measured for the complete oxidation of ethanol and toluene, individually and in binary mixture. Complete oxidation reactions were carried out at atmospheric pressure in a stainless steel tubular fixed-bed reactor of $45 \mathrm{~cm}$ high and $2.3 \mathrm{~cm}$ in inner diameter. A feed gas with a VOC concentration of $1,000 \mathrm{mgC} \mathrm{m}^{-3}$ in air and a total flow of $1,000 \mathrm{~cm}^{3} \mathrm{~min}^{-1}$ (GHSV $=12,000 \mathrm{~h}^{-1}$ ) was passed through the monolith placed on the top of a carborundum bed. This configuration was designed to premix and preheat the stream entering the reactor, to obtain a homogeneous temperature at the 
monolith inlet, measured by a thermocouple placed just at the entrance of the monolith. The reactor was surrounded by an electrical furnace equipped with three independent temperature programmers. The ignition curves were obtained over the range $100-450{ }^{\circ} \mathrm{C}$ in incremental steps $\left(25^{\circ} \mathrm{C}\right)$ and the reaction temperature was measured by a thermocouple placed in the middle of the monolith. The data were obtained in steady state. Monoliths were treated under $1,000 \mathrm{~cm}^{3} \mathrm{~min}^{-1}$ of air at $450{ }^{\circ} \mathrm{C}$ for $1 \mathrm{~h}$ before reaction, and then cooled down in air to the starting reaction temperature. The conversion was calculated by measuring VOC disappearance by gas chromatography (Shimadzu GC9A), together with the $\mathrm{CO}_{2}$ measurement by an on-line IR detector (Telaire T6613). The yield to $\mathrm{CO}_{2}$ was calculated as the ratio between the $\mathrm{CO}_{2}$ concentrations divided by its value measured when complete conversion at high temperature had been reached. No partial oxidation products were detected in the combustion of toluene. In the case of ethanol oxidation, the acetaldehyde yield was calculated as moles of ethanol converted to acetaldehyde divided by the moles of ethanol fed into the reactor. In the oxidation of the binary VOC mixture, the feed composition was kept at $1,000 \mathrm{mgC} \mathrm{m}^{-3}$.

\section{Results}

\section{Catalyst characterization}

The platinum content in the monoliths, determined by atomic spectroscopy, was $0.22 \mathrm{wt} \%$ for $\mathrm{Pt} / \mathrm{B}$ and $0.23 \mathrm{wt} \%$ for $\mathrm{Pt} / \mathrm{Mn} / \mathrm{B}$. The manganese content was $2.0 \mathrm{wt} \%$ for $\mathrm{Mn} / \mathrm{B}$ and $1.9 \mathrm{wt} \%$ for $\mathrm{Pt} / \mathrm{Mn} / \mathrm{B}$.

Table 1 lists the results of nitrogen physisorption obtained for the supported catalysts. The BET surface area of the support was $53 \mathrm{~m}^{2} \mathrm{~g}^{-1}$. After platinum impregnation, the surface area decreased significantly to $35 \mathrm{~m}^{2} \mathrm{~g}^{-1}$. This decrease in the BET surface area upon Pt impregnation is attributed to a fraction of platinum crystallites blocking the smaller pores of the support and thereby increasing the average pore radius from 124 to $167 \AA$. Impregnation of the bentonite support with manganese does not significantly change the textural properties. The addition of $\mathrm{Pt}$ to $\mathrm{Mn} / \mathrm{B}$ has no effect on the specific area.

Table 1 Textural properties and XPS results of monoliths

\begin{tabular}{|c|c|c|c|c|c|c|}
\hline Catalyst & $S_{\mathrm{BET}}\left(\mathrm{m}^{2} \mathrm{~g}^{-1}\right)$ & $V_{\mathrm{p}}\left(\mathrm{cm}^{3} \mathrm{~g}^{-1}\right)$ & $D_{\mathrm{p}}(\AA)$ & Weight loss (\%) & $\mathrm{Mn} 2 \mathrm{p}_{3 / 2}(\mathrm{eV})$ & $\mathrm{Pt} 4 \mathrm{~d}_{5 / 2}(\mathrm{eV})$ \\
\hline B & 53 & 0.16 & 124 & 0.98 & & \\
\hline $\mathrm{Pt} / \mathrm{B}$ & 35 & 0.15 & 167 & 0.99 & & $\begin{array}{l}315.2 \\
318.4\end{array}$ \\
\hline $\mathrm{Mn} / \mathrm{B}$ & 57 & 0.16 & 115 & 1.1 & $\begin{array}{l}641.1(58 \%) \\
643.1(42 \%)\end{array}$ & \\
\hline $\mathrm{Pt} / \mathrm{Mn} / \mathrm{B}$ & 58 & 0.15 & 75 & 0.98 & $\begin{array}{l}641.7(80 \%) \\
644.9(20 \%)\end{array}$ & 317.1 \\
\hline
\end{tabular}


SEM micrographs of catalysts are shown in Fig. 1a-d. It can be seen that the solid Pt/B (Fig. 1b) has a morphology similar to that of the support (Fig. 1a), while the solid $\mathrm{Mn} / \mathrm{B}$ and $\mathrm{Pt} / \mathrm{Mn} / \mathrm{B}$ (Fig. 1c, d) shows a cluster of small surface particles on the support matrix. In the $\mathrm{Mn} / \mathrm{B}$ catalyst, the $\mathrm{MnO}_{\mathrm{x}}$ layer is deposited on the support surface changing its morphology.

The adherence of catalyst after the ultrasound test showed an approximately $1 \mathrm{wt} \%$ weight lost (Table 1).

The XRD patterns of the samples are shown in Fig. 2. The diffraction pattern of the support shows the diffraction lines corresponding to the support, $\mathrm{Al}_{2} \mathrm{O}_{3}$ and bentonite. $\mathrm{Mn} / \mathrm{B}, \mathrm{Pt} / \mathrm{B}$ and $\mathrm{Pt} / \mathrm{Mn} / \mathrm{B}$ samples present the diffraction lines of the support. Manganese oxides were not detected in $\mathrm{Mn} / \mathrm{B}$ or in $\mathrm{Pt} / \mathrm{Mn} / \mathrm{B}$ catalysts. Metallic Pt or platinum oxides were neither detected in the samples containing platinum.

In the XPS studies, the energy regions of $\mathrm{Mn} 2 \mathrm{p}_{3 / 2}$ and $\mathrm{Pt} 4 \mathrm{~d}_{5 / 2}$ core levels were recorded. Although the most intense photoemission lines of platinum were those
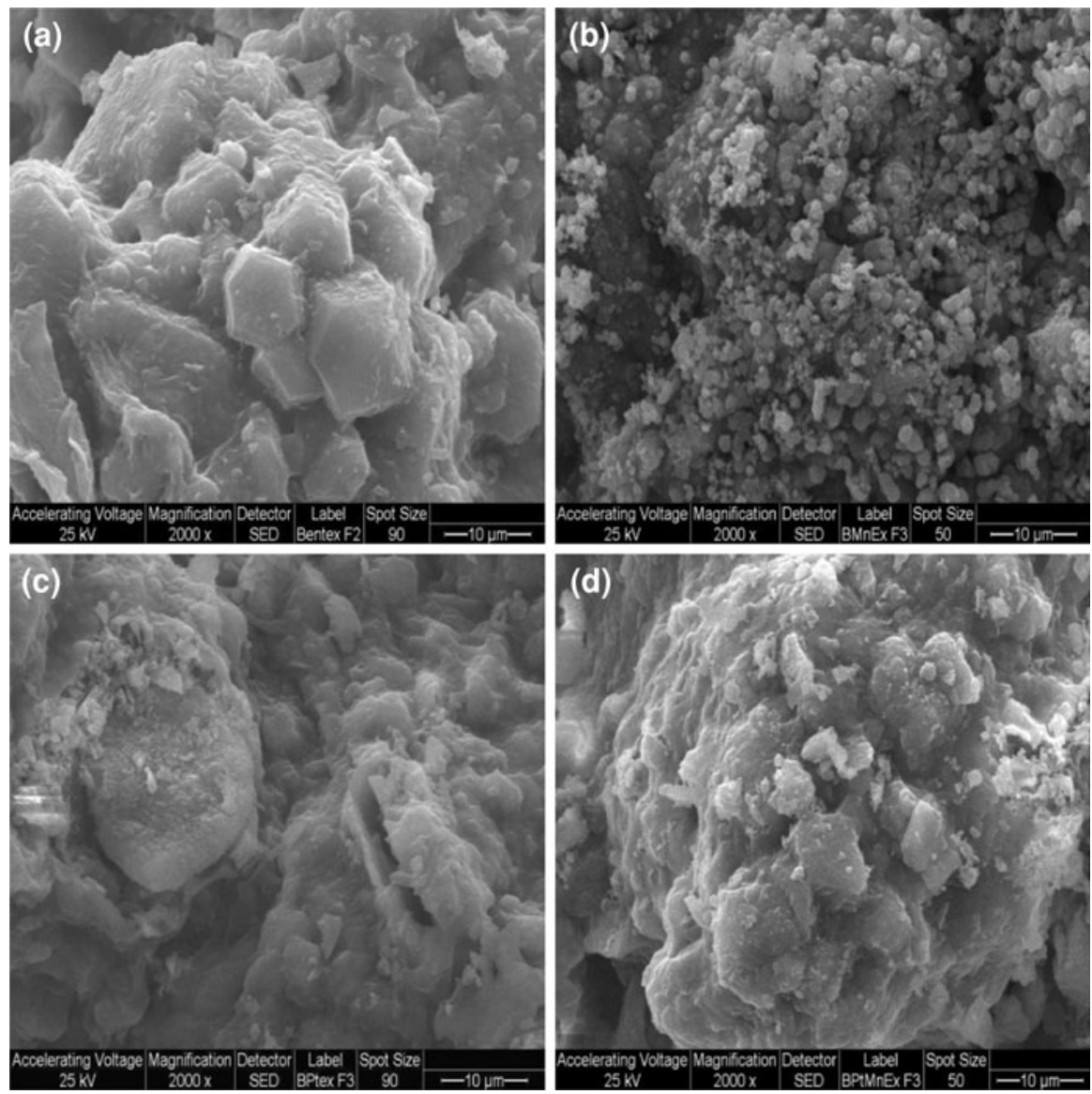

Fig. 1 SEM micrographs of monoliths, a bentonite, b $\mathrm{Mn} / \mathrm{B}, \mathbf{c} \mathrm{Pt} / \mathrm{B}$ and $\mathbf{d} \mathrm{Pt} / \mathrm{Mn} / \mathrm{B}$ 


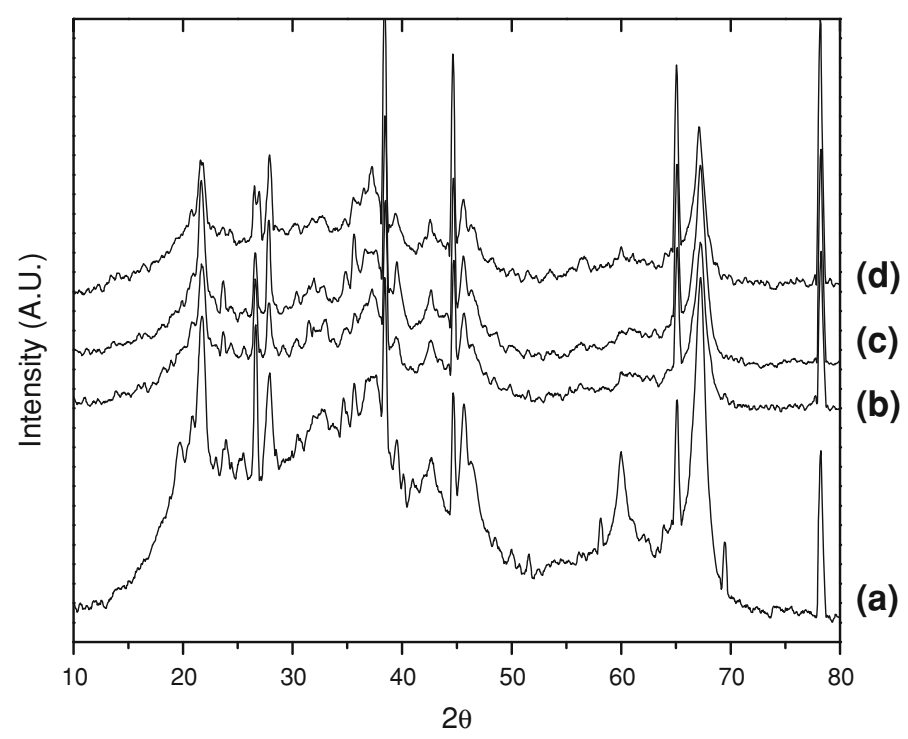

Fig. 2 X-ray diffraction patterns of samples: (a) bentonite, $(b) \mathrm{Mn} / \mathrm{B},(c) \mathrm{Pt} / \mathrm{B}$ and $(d) \mathrm{Pt} / \mathrm{Mn} / \mathrm{B}$

arising from the $\mathrm{Pt} 4 \mathrm{f}$ levels, this energy region was overshadowed by the presence of a very strong Al 2p peak, and thus the Pt 4d lines were analyzed instead [29]. The spectra of $\mathrm{Mn} 2 \mathrm{p}_{3 / 2}$ for $\mathrm{Mn} / \mathrm{B}$ and $\mathrm{Pt} / \mathrm{Mn} / \mathrm{B}$ monoliths are presented in Fig. 3a and the $\mathrm{Mn} 2 \mathrm{p}_{3 / 2}$ binding energies are also presented in Table 1. For both catalysts, $\mathrm{Mn} / \mathrm{B}$ and $\mathrm{Pt} / \mathrm{Mn} / \mathrm{B}$, the $\mathrm{Mn} 2 \mathrm{p}_{3 / 2}$ spectral shape could be reproduced with two Mn $2 \mathrm{p}_{3 / 2}$ components assigned to $\mathrm{Mn}^{3+}$ and $\mathrm{Mn}^{4+}$ [30]. Nevertheless, the addition of platinum to manganese oxide increased the $\mathrm{Mn}^{3+} / \mathrm{Mn}^{4+}$ ratio remarkably.

The spectra of $\mathrm{Pt} 4 \mathrm{~d}_{5 / 2}$ are presented in Fig. $3 \mathrm{~b}$. The $\mathrm{Pt} / \mathrm{B}$ sample showed an asymmetric broad $\mathrm{Pt} 4 \mathrm{~d}_{5 / 2}$ peak that could be resolved, after curve fitting procedures, into two components with binding energies of 318.4 and $315.2 \mathrm{eV}$. The component at higher binding energy can be ascribed to $\mathrm{PtO}_{2}$ species $[29,31]$, whereas the second band at lower binding energy can be assigned to the presence of $\mathrm{Pt}$ (II) species [32]. Pt/Mn/B monoliths showed a $\mathrm{Pt} 4 \mathrm{~d}_{5 / 2}$ peak that the curve fitting give just one component at $317.1 \mathrm{eV}$ assigned to $\mathrm{PtO}_{2}$ [31].

The reduction behavior of $\mathrm{Pt} / \mathrm{B}, \mathrm{Mn} / \mathrm{B}$ and $\mathrm{Pt} / \mathrm{Mn} / \mathrm{B}$ catalysts was followed by $\mathrm{H}_{2}$-TPR, as shown in Fig. 4. In Mn/B monolith, a shoulder at lower temperature $\left(310{ }^{\circ} \mathrm{C}\right)$ is related to the reduction of highly dispersed $\mathrm{MnO}_{\mathrm{x}}$ species [33-35]. Additionally, two reduction peaks centered at 409 and $495{ }^{\circ} \mathrm{C}$ are observed. The first reduction peak corresponded to the combined reduction of $\mathrm{MnO}_{2}$ or $\mathrm{Mn}_{2} \mathrm{O}_{3}$ to $\mathrm{Mn}_{3} \mathrm{O}_{4}$ [36], and the second reduction peak could represents the reduction of $\mathrm{Mn}_{3} \mathrm{O}_{4}$ to $\mathrm{MnO}$ [36] or the reduction of $\mathrm{Mn}_{5} \mathrm{O}_{8}$ to $\mathrm{MnO}$ [37]. Furthermore, the TPR pattern reveals a peak at about $680{ }^{\circ} \mathrm{C}$, which could be associated to the reduction of $\mathrm{Mn}^{3+}$ to $\mathrm{Mn}^{2+}$ ions incorporated in the support lattice [35, 38]. Platinum in the mixed manganese oxide/platinum catalyst significantly affects the reduction behavior of the oxide. The TPR-profile changes in several ways: the shape of the curves, the 

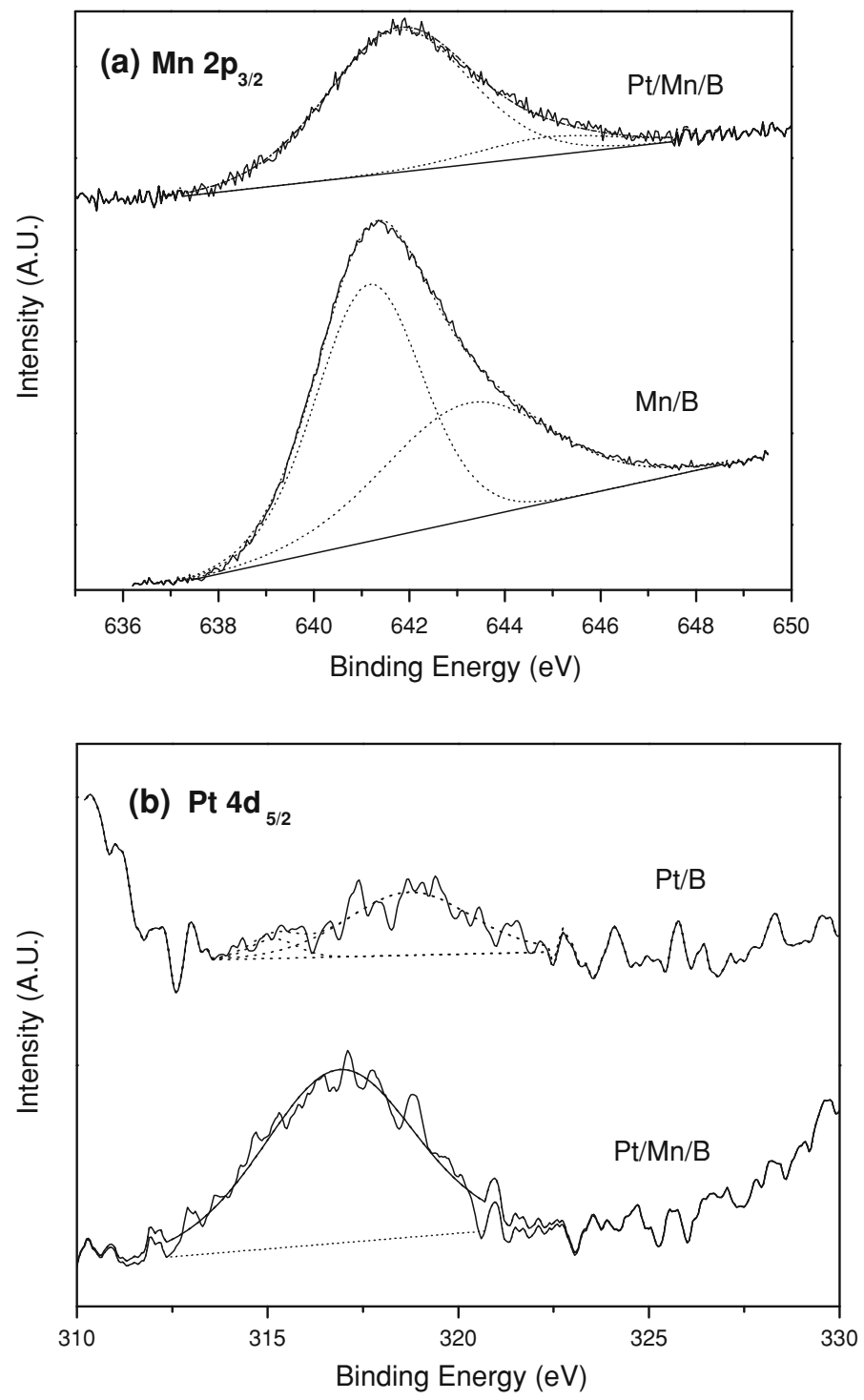

Fig. 3 Mn $2 p_{3 / 2}$ (a) and Pt $4 d_{5 / 2}$ (b) XPS spectra of samples

number of peaks, the reduction rate and temperature. A possible explanation for that could be that platinum and manganese are in intimate contact and therefore can affect each other by the spillover of hydrogen atoms from platinum to manganese or by nucleation of hydrogen molecules to atoms by platinum making the hydrogen more reactive $[39,40]$.

From the TPR results, the calculated average oxidation state of Mn was 3.62 for $\mathrm{Mn} / \mathrm{B}$ and 3.60 for $\mathrm{Pt} / \mathrm{Mn} / \mathrm{B}$. This effect was observed by another author [41]. 


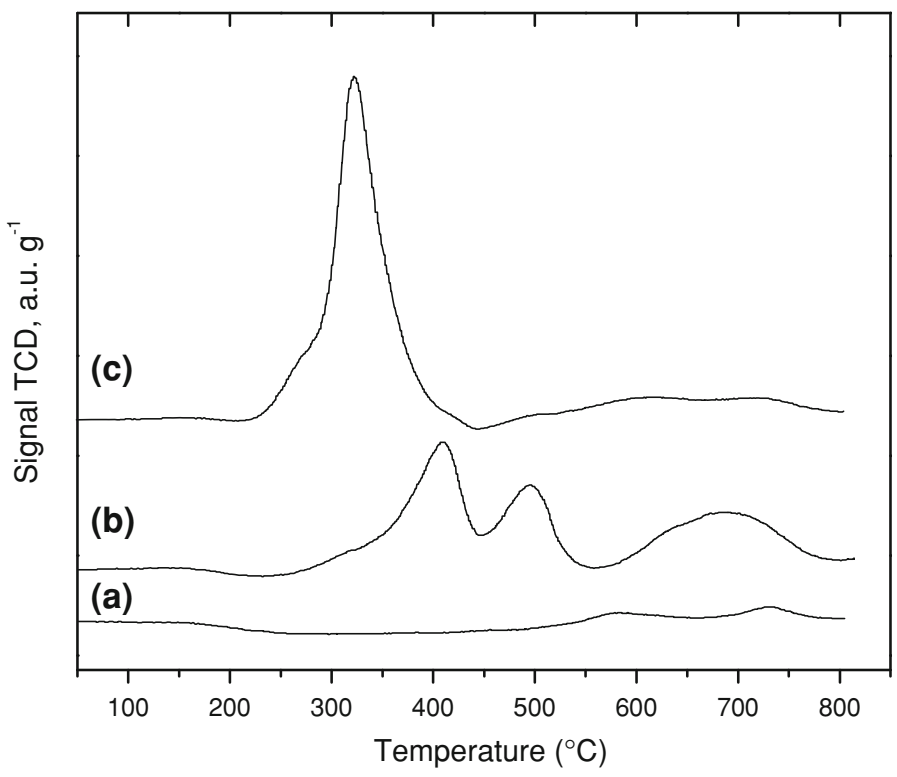

Fig. 4 TPR profiles of samples: (a) Pt/B; (b) Mn/B and (c) Pt/Mn/B

Catalytic activity

\section{Catalytic oxidation of individual compounds}

The catalytic activity of supported $\mathrm{Pt}, \mathrm{Mn}$ and $\mathrm{Pt} / \mathrm{Mn}$ bentonite monoliths towards the oxidation of each VOC, ethanol and toluene, is presented in Fig. 5. For comparison, the activity of the bentonite support is also presented. Additionally, the temperatures for 10,50 and $90 \%$ conversion into $\mathrm{CO}_{2}$ are listed in Table 2 . In the three catalysts, ethanol is more easily oxidized than toluene, in accordance with other authors [42,43].

The addition of $\mathrm{Pt}$ to $\mathrm{Mn}$ greatly improves the oxidation of ethanol, lowering the $T_{50}$ and $T_{90}$ to about 40 and $30{ }^{\circ} \mathrm{C}$, respectively.

On the other hand, the activity towards ethanol oxidation of both catalysts containing platinum, $\mathrm{Pt} / \mathrm{Mn} / \mathrm{B}$ and $\mathrm{Pt} / \mathrm{B}$, is rather similar, the bimetallic catalyst being a little more active at temperatures above $200{ }^{\circ} \mathrm{C}$. In fact, the $T_{90}$ of $\mathrm{Pt} / \mathrm{Mn} / \mathrm{B}$ monolith is $10{ }^{\circ} \mathrm{C}$ lower than that of $\mathrm{Pt} / \mathrm{B}$.

Apart from $\mathrm{CO}_{2}$ and $\mathrm{H}_{2} \mathrm{O}$, a product of ethanol incomplete oxidation (acetaldehyde) was detected. As was observed in previous work [44], the oxidation of ethanol may run according to the following scheme:

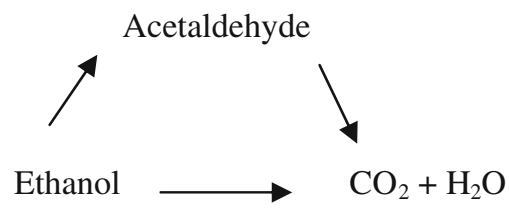




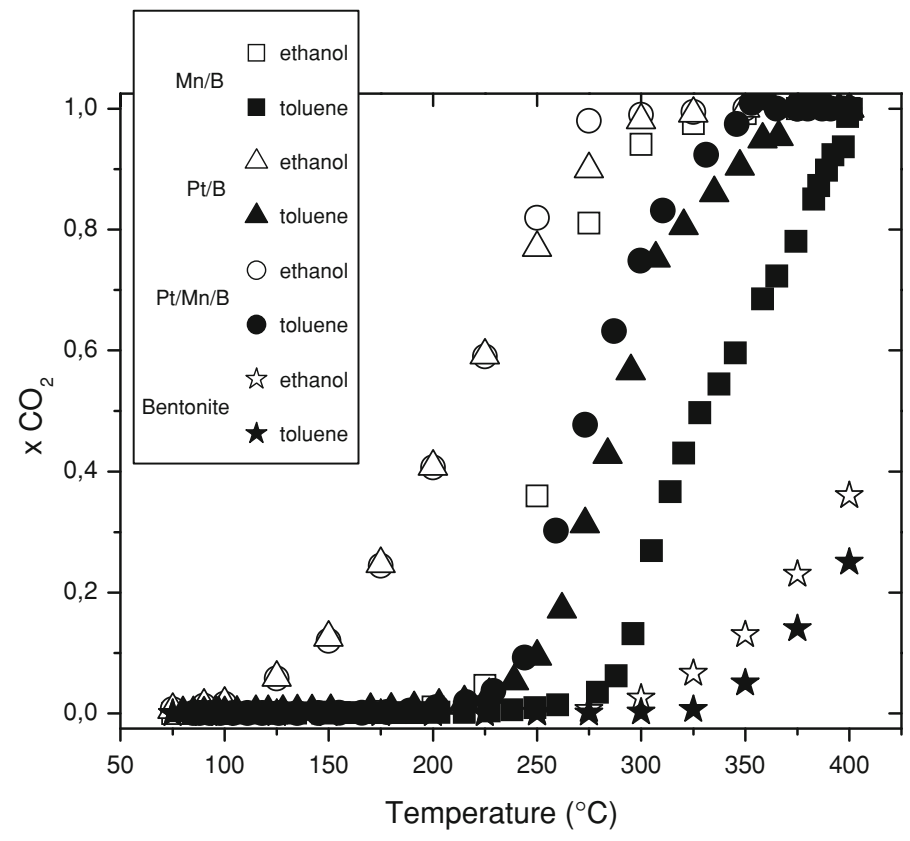

Fig. 5 Ethanol and toluene ignition curves over monoliths

Table 2 Catalytic activity of pure compounds expressed as $T_{10}, T_{50}$ and $T_{90}\left({ }^{\circ} \mathrm{C}\right)$ (temperatures at $\mathrm{CO}_{2}$ conversion of 10,50 and $90 \%$ )

\begin{tabular}{llllllll}
\hline Catalyst & \multicolumn{2}{l}{ Ethanol } & \multicolumn{5}{l}{ Toluene } \\
\cline { 2 - 3 } \cline { 7 - 8 } & $T_{10}$ & $T_{50}$ & $T_{90}$ & & $T_{10}$ & $T_{50}$ & $T_{90}$ \\
\hline $\mathrm{Mn} / \mathrm{B}$ & 229 & 256 & 294 & & 292 & 327 & 389 \\
$\mathrm{Pt} / \mathrm{B}$ & 145 & 212 & 278 & & 254 & 288 & 349 \\
$\mathrm{Pt} / \mathrm{Mn} / \mathrm{B}$ & 145 & 212 & 265 & & 244 & 276 & 324 \\
\hline
\end{tabular}

Fig. 6 shows the production of acetaldehyde as a function of the reaction temperature. Although the aldehyde is the most abundant intermediate, acetaldehyde yield did not exceed $6 \%$ for $\mathrm{Pt} / \mathrm{Mn} / \mathrm{B}$ and $3 \%$ for $\mathrm{Pt} / \mathrm{B}$. For $\mathrm{Mn} / \mathrm{B}$ the acetaldehyde yield is negligible. The maximum of acetaldehyde occurs at around 200 and $225^{\circ} \mathrm{C}$ for $\mathrm{Pt} / \mathrm{Mn} / \mathrm{B}$ and $\mathrm{Pt} / \mathrm{B}$, respectively.

As can be seen in Fig. 5 and Table 2, the activity towards toluene oxidation markedly decreases in the order of $\mathrm{Pt} / \mathrm{Mn} / \mathrm{B}>\mathrm{Pt} / \mathrm{B}>\mathrm{Mn} / \mathrm{B}$. As in the case of ethanol oxidation, the addition of $\mathrm{Pt}$ to $\mathrm{Mn}$ enhanced toluene conversion, lowering the $T_{50}$ and $T_{90}$ to about 50 and $60{ }^{\circ} \mathrm{C}$, respectively. On the other hand, no partial oxidation products were detected in toluene oxidation.

In accord with the TPR results, the reduction of the $\mathrm{Mn} / \mathrm{B}$ catalyst occurs at higher temperatures than in $\mathrm{Pt} / \mathrm{Mn} / \mathrm{B}$, and consequently the oxidation of VOCs on the $\mathrm{Mn} / \mathrm{B}$ catalyst was more difficult than that on the $\mathrm{Pt} / \mathrm{Mn} / \mathrm{B}$ catalyst. It may be 


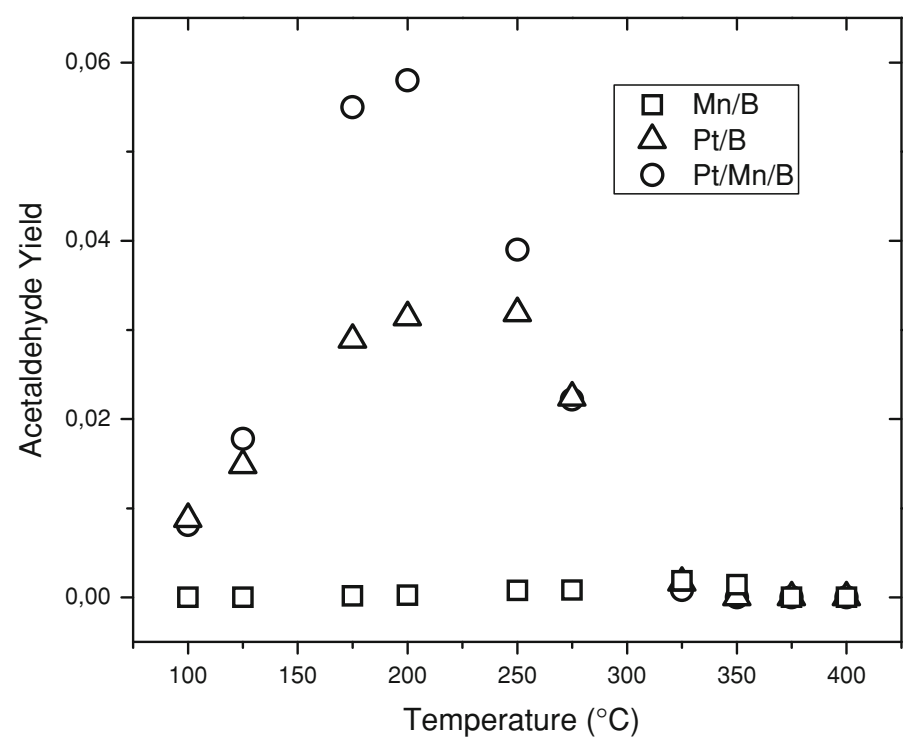

Fig. 6 Evolution of acetaldehyde yield with reaction temperature

assumed that the higher activity for the bimetallic catalysts resulted from the valence state as well as the favorable synergetic effects between $\mathrm{Pt}$ and $\mathrm{Mn}$.

It has been reported that the activity towards the oxidation of VOCs of manganese oxide-based catalysts is related to the presence of the $\mathrm{Mn}^{3+}-\mathrm{Mn}^{4+}$ redox couple $[45,46]$. As we observed in XPS experiments, the $\mathrm{Mn}^{3+} / \mathrm{Mn}^{4+}$ surface ratio increases when Pt is added to Mn. In previous work [47], in the oxidation of ethanol on manganese oxides prepared from $\mathrm{KMnO}_{4}$ and $\mathrm{Mn}\left(\mathrm{NO}_{3}\right)_{2}$, we assumed that a high concentration of $\mathrm{Mn}^{3+}$ could originate a weak $\mathrm{Mn}-\mathrm{O}$ bond and the formation of more active oxygen species in the lattice, which would improve $\mathrm{H}$ subtraction from the adsorbed alcohol molecule. Although the combustion of ethanol is independent of the presence of $\mathrm{Mn}$, the synergetic effect of $\mathrm{Pt}-\mathrm{Mn}$ is important when toluene is analyzed. The temperatures $T_{10}, T_{50}$ and $T_{90}$ on $\mathrm{Pt} / \mathrm{Mn} / \mathrm{B}$ are lower than that of Pt/B. These results are similar to that reported by Sanz et al. [48]. The authors have shown that "Pt improved the catalytic activity of $\mathrm{MnO}_{\mathrm{x}}$ decreasing the complete toluene oxidation temperature from 300 to $265{ }^{\circ} \mathrm{C}\left(25^{\circ} \mathrm{C}\right.$ in this work)". In our opinion, this result demonstrates that $\mathrm{Pt}$ and the presence of $\mathrm{Mn}^{3+} / \mathrm{Mn}^{4+}$ redox couple is crucial.

The acidity of the samples was evaluated by titration with $n$-butylamine. Results are presented in Fig. 7. Taking into account the acidity properties of the samples, the support has no effect on the reaction. Additionally, toluene conversion depends on the acidity of the samples, the more the acidity of the samples the more the toluene conversion.

Acetaldehyde formation could be associated to an interaction between the $\mathrm{OH}$ of the ethanol and a Pt site of the solid.

The $\mathrm{Pt}-\mathrm{Mn}$ interaction in $\mathrm{Pt} / \mathrm{Mn} / \mathrm{B}$ monolith could be results in a mayor acetaldehyde formation. The increased acidity in $\mathrm{Pt} / \mathrm{Mn} / \mathrm{B}$ sample originates an 


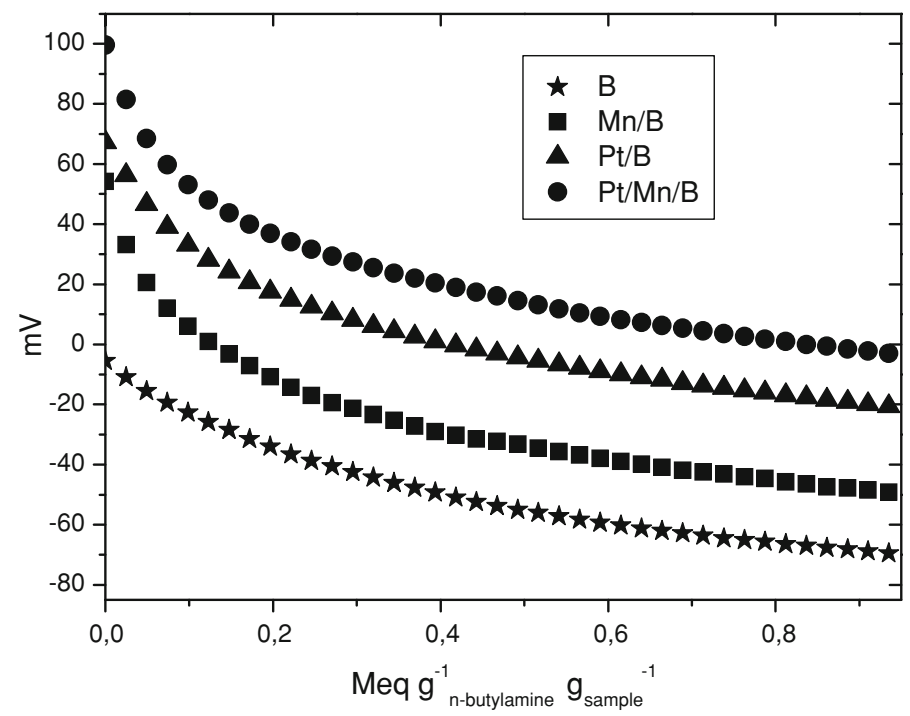

Fig. 7 Titration of samples with $n$-butylamine

increased donor character of ethanol, a phenomenon that results in the formation of adsorbed inactive spectators according with Peluso et al. [28].

Nevertheless, the higher catalytic activity of the $\mathrm{Pt} / \mathrm{Mn} / \mathrm{B}$ monolith could be associated to an increase in the amount of surface $\mathrm{Mn}^{3+}$ species, resulting in a higher capacity of combustion of adsorbed intermediate species [47].

The $\mathrm{Pt} / \mathrm{Mn} / \mathrm{B}$ monolith presents a promissory activity in the combustion of VOCs. Working at a GHSV of $12,000 \mathrm{~h}^{-1}$, a $T_{90}$ of 265 and $324{ }^{\circ} \mathrm{C}$ is obtained for ethanol and toluene, respectively. Burgos et al. [19] oxidized toluene over cylindrical $\mathrm{Pt} / \mathrm{Al}_{2} \mathrm{O}_{3} / \mathrm{Al}$ monoliths (330 cpi, $6 \mathrm{~cm}^{3}$ volume) at lower temperature but working at a GHSV of $3,680 \mathrm{~h}^{-1}$. Morales et al. [34] obtained a $T_{90}$ of 210 and $300{ }^{\circ} \mathrm{C}$ for ethanol and toluene, respectively, over $\mathrm{MnCu}$ supported on $330 \mathrm{cpi}$ cylindrical Fecralloy monoliths working at a GHSV of $3,000 \mathrm{~h}^{-1}$. Li et al. [49] studied the combustion of toluene over $0.2 \% \mathrm{Pd}-6 \% \mathrm{Ce}_{x} \mathrm{La}_{1-x} \mathrm{O}_{2}$ supported on 200 cpi cordierite monoliths $\left(48 \times 24 \times 40 \mathrm{~mm}^{3}\right)$ working at $0.3 \mathrm{~m}^{3} \mathrm{~h}^{-1}$, obtained $90 \%$ toluene conversion at $230{ }^{\circ} \mathrm{C}$. Monoliths prepared in this work are easy to obtain and are ready made to incorporate the active phase directly by wet impregnation.

\section{Ethanol-toluene binary mixture}

The activity of the monoliths in a mixture of ethanol and toluene (with the same total concentration as in the individual compounds) was also investigated. Fig. 8a shows the results of the total combustion to $\mathrm{CO}_{2}$. It can be observed that $\mathrm{Pt} / \mathrm{Mn} / \mathrm{B}$ presents the highest initial activity towards the combustion of the VOC mixture; however, the three catalysts achieve complete oxidation to $\mathrm{CO}_{2}$ at almost $350{ }^{\circ} \mathrm{C}$. 
Fig. 8b presents the conversion of ethanol and toluene in the mixture. For the three catalysts, ethanol again was more easily oxidized than toluene. The performance of the monoliths for the combustion of the two VOCs, ethanol and toluene, follows the order: $\mathrm{Pt} / \mathrm{Mn} / \mathrm{B}>\mathrm{Pt} / \mathrm{B}>\mathrm{Mn} / \mathrm{B}$. The same order of activity was found in the oxidation of toluene alone. In the oxidation of ethanol alone, $\mathrm{Pt} / \mathrm{Mn} / \mathrm{B}$ presented similar activity to that of $\mathrm{Pt} / \mathrm{B}$ at temperatures below $200{ }^{\circ} \mathrm{C}$, being more active at higher temperatures. In the VOCs mixture, $\mathrm{Pt} / \mathrm{Mn} / \mathrm{B}$ is more active than $\mathrm{Pt} / \mathrm{B}$ even at low temperatures.
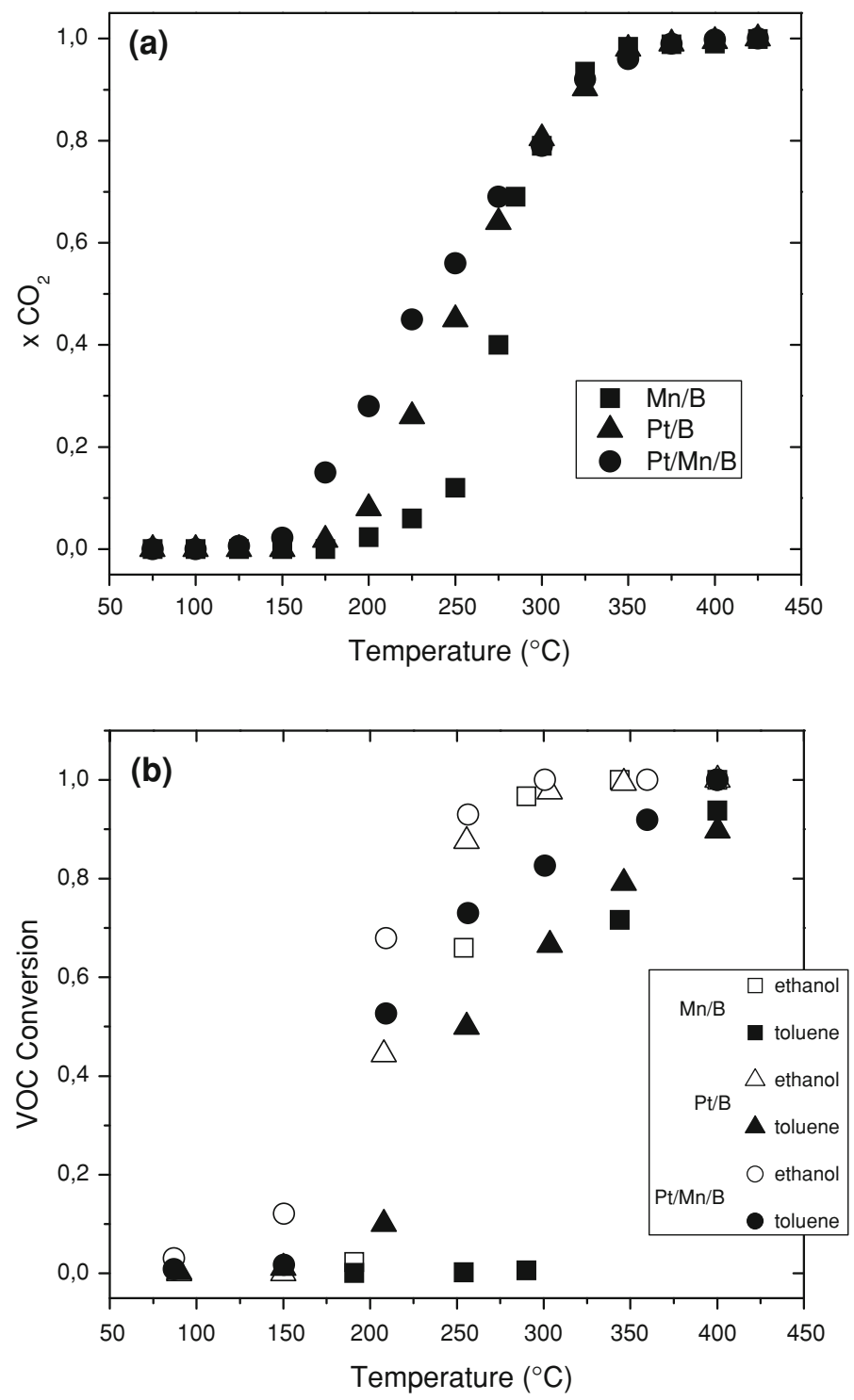

Fig. 8 Total conversion (a) and partial conversion (b) of ethanol and toluene in the VOC mixture 
The least active monolith, $\mathrm{Mn} / \mathrm{B}$, presents a high activity towards ethanol oxidation, whereas toluene oxidation starts when almost complete ethanol conversion has been obtained at about $290{ }^{\circ} \mathrm{C}$.

Taking into account the formation of intermediate products, the presence of toluene modified the selectivity of ethanol to acetaldehyde. Fig. 9 shows the acetaldehyde yield as a function of the reaction temperature in the ethanol-toluene mixture. For the three monoliths, the curves of ethanol conversion to acetaldehyde are shifted to higher temperatures. This effect was also observed by other authors $[19,50]$. Additionally, higher values of maximum acetaldehyde yield are observed, especially in $\mathrm{Mn} / \mathrm{B}$ monolith. Agüero et al. [51] have found that the presence of toluene increases the acetaldehyde yield in the combustion of the ethanol-toluene mixture over an alumina-supported manganese oxide.

According to different authors [52-54], the total oxidation of toluene occurs when the molecule is adsorbed in parallel to the surface. Our previous results [44] have shown that the adsorption-oxidation of ethanol occurs on two sites: (i) terminal oxygen and (ii) $\mathrm{OH}$ groups formed from $\mathrm{Mn}^{4+}$ vacancies. These results allow us to suggest that the toluene adsorption blocks the catalytic sites where ethanol can be oxidized directly to $\mathrm{CO}_{2}$. Then, the acetaldehyde formation is more favorable.

The presence of ethanol enhanced toluene oxidation, especially in the catalyst containing platinum. The $T_{50}$ decreased from 276 to $207{ }^{\circ} \mathrm{C}$ and 291 to $256{ }^{\circ} \mathrm{C}$ in $\mathrm{Pt} / \mathrm{Mn} / \mathrm{B}$ and $\mathrm{Pt} / \mathrm{B}$, respectively, when toluene was oxidized alone and in the mixture with ethanol. This effect is most probably a consequence of the higher exothermicity of the process when the mixtures are considered, as was reported by other authors in ethanol-toluene mixtures $[43,50]$.

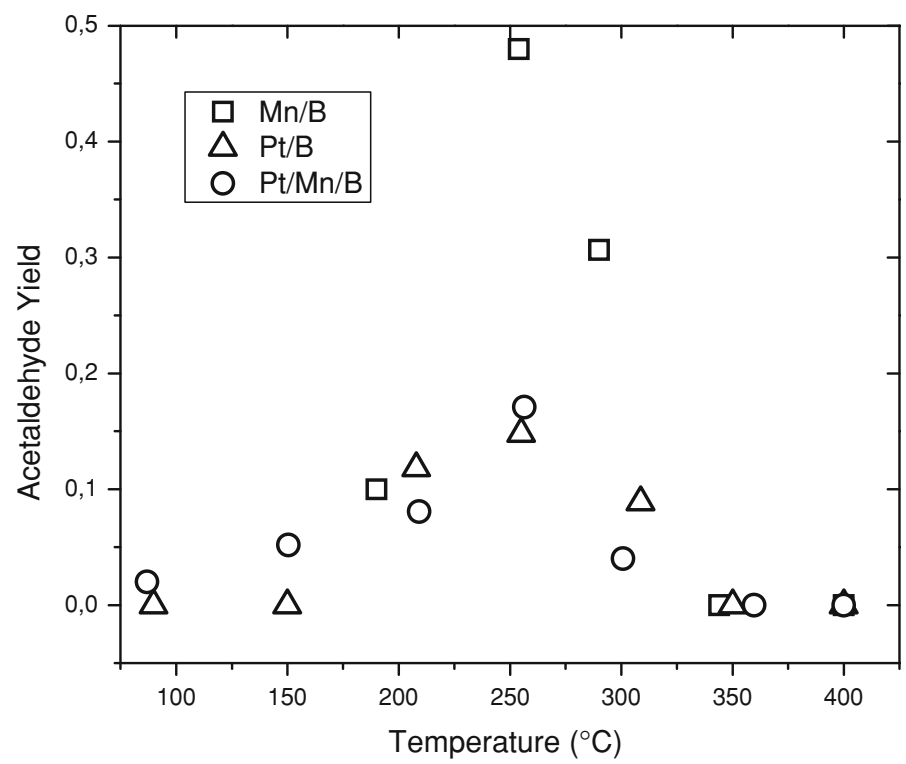

Fig. 9 Evolution of acetaldehyde yield with reaction temperature in the ethanol-toluene mixture 
The studies carried out in this work demonstrated that the $\mathrm{Pt} / \mathrm{MnO}_{\mathrm{x}}$ active phase supported on bentonite monolith is a promising catalyst for VOCs abatement. Further investigation in different shapes and different materials for monolith supports is currently being carried out in our laboratory.

\section{Conclusions}

Ceramic monoliths using natural bentonites as raw materials were prepared. The relatively high surface area of the support allows the incorporation of the active phases (Mn, Pt and Pt/Mn) directly by wet impregnation. The impregnated phases show excellent adhesion to the monoliths. The XRD analyses shows only the diffraction peaks of the support and no metallic platinum or manganese oxides phases were detected. The addition of Pt to $\mathrm{Mn}$ increases the surface $\mathrm{Mn}^{3+} / \mathrm{Mn}^{4+}$ ratio in comparison to $\mathrm{Mn} / \mathrm{B}$ and facilitates the reduction of the manganese oxide phases. The acidity of the samples decrease in the order: $\mathrm{Pt} / \mathrm{Mn} / \mathrm{B}>$ $\mathrm{Pt} / \mathrm{B}>\mathrm{Mn} / \mathrm{B}>\mathrm{B}$.

The catalytic activity in toluene oxidation was in the order $\mathrm{Pt} / \mathrm{Mn} / \mathrm{B}>$ $\mathrm{Pt} / \mathrm{B}>\mathrm{Mn} / \mathrm{B}>\mathrm{B}$. In ethanol oxidation, the conversion order was: $\mathrm{Pt} / \mathrm{Mn} / \mathrm{B}=$ $\mathrm{Pt} / \mathrm{B}>\mathrm{Mn} / \mathrm{B}>\mathrm{B}$. Although the combustion of ethanol is independent of the presence of $\mathrm{Mn}$, a favorable synergetic effect between $\mathrm{Pt}$ and $\mathrm{Mn}$ is important when toluene is analyzed, together with the increase in the surface $\mathrm{Mn}^{3+} / \mathrm{Mn}^{4+}$ ratio, and the increase in the catalysts acidity.

In the VOC mixture, the presence of toluene shifts the curve of ethanol oxidation towards acetaldehyde to higher temperatures. On the other hand, the presence of ethanol has a promoting effect on toluene oxidation, attributed to a local heating effect.

Acknowledgments The author thanks Lilian Osiglio (CINDECA) for the acidity measurements.

\section{References}

1. Horsley JA (1993) Catalytica environmental report no. E4. Catalytica Studies Division, Mountain View

2. Spivey J (1987) Ind Eng Chem Res 26:2165-2180

3. Armor JN (1992) Appl Catal B 1:221-256

4. Hermia J, Vigneron S (1993) Catal Today 17:349-358

5. Jin L, He M, Lu J, Luo M, Gao L, He J (2008) J Rare Earths 26:614-618

6. Saqer S, Kondarides D, Verykios X (2009) Top Catal 52:517

7. Lamonier JF, Boutoundou A, Boutoundou C, Perez-Zurita M, Siffert S, Aboukais A (2007) Catal Lett 118:165-172

8. Jiratova K, Mikulova J, Klempa J, Grygar T, Bastl Z, Kovanda F (2009) Appl Catal A 361:106-116

9. Palacio L, Velasquez J, Echavarria A, Faro A, Ribeiro F, Ribeiro M (2010) J Hazard Mater 177:407-413

10. Lu H, Zhou Y, Huang H, Zhang B, Chen Y (2011) J Rare Earths 29:855-860

11. Avila P, Montes M, Miro EE (2005) Chem Eng J 109:11-36

12. Agüero F, Barbero B, Costa-Almeida L, Montes M, Cadus L (2011) Chem Eng J 166:218-223

13. Gatica J, Vidal H (2010) J Hazard Mater 181:9-18 
14. Dominguez M, Barrio I, Sanchez M, Centeno M, Montes M, Odriozola J (2008) Catal Today 133: 467-474

15. Barrio I, Legorburu I, Montes M, Dominguez M, Centeno M, Odriozola J (2005) Catal Lett 101: $151-157$

16. Santos V, Carabineiro S, Tavares P, Pereira M, Orfao J, Figueiredo J (2010) Appl Catal B 99: 198-205

17. Tsou J, Magnoux P, Guisnet M, Orfao J, Figueiredo J (2005) Appl Catal B 57:117-123

18. Kim S, Shim W (2010) Appl Catal B 98:180-185

19. Burgos N, Paulis M, Mirari Antxustegi M, Montes M (2002) Appl Catal B 38:251-258

20. Benbow J, Bridgwater J (1993) Paste flow and extrusion. Clarendon Press, Oxford

21. Graczyk J, Gleissie W (1990) Petrochimie 43:27-30

22. Komova O, Simakov A, Kovalenko G, Rudina N, Chuenko T, Kulikovskaya N (2007) Kinet Catal 48:803-811

23. Forzatti P, Ballardini D, Sighicelli L (1998) Catal Today 41:87-94

24. Williams JL (2001) Catal Today 69:3-9

25. Lombardi B, Baschini M, Torres Sanchez R (2003) Appl Clay Sci 22:309-312

26. Kiurski J, Branislav M, Adamovic D, Mihailovic A, Grujic S, Oros I, Krstc J (2012) Renew Sust Energy Rev 16:660-667

27. Wolf M (1994) Stud Environ Sci 61:29-34

28. Peluso MA, Pronsato E, Sambet JE, Thomas HJ, Busca G (2008) Appl Catal B 78:73-79

29. Serrano-Ruiz J, Huber G, Sánchez-Castillo M, Dumesic J, Rodríguez-Reinoso F, SepúlvedaEscribano A (2006) J Catal 241:378-388

30. Ponce S, Peña M, Fierro J (2000) Appl Catal B 24:193-205

31. Serre C, Garin F, Belot G, Maire G (1993) J Catal 141:1-8

32. Shyu J, Otto K (1998) Appl Surf Sci 32:246-252

33. Liu X, Lu J, Qian K, Huang W, Luo M (2009) J Rare Earths 27(418):424

34. Morales M, Barbero B, Lopez T, Moreno A, Cadús L (2009) Fuel 88:2122-2129

35. Trawczynski J, Bielak B, Mista W (2005) Appl Catal B 55:277-285

36. Kapteijn F, Van Langeveld A, Moulijn J, Andreini A, Vuuman M, Turek A, Jehng J, Wachs I (1994) J Catal 150:94-104

37. Mirzaei A, Shaterian H, Habibi M, Hutchings G, Taylor S (2003) Appl Catal A 253:499-508

38. Dobber D, Kiebling D, Schmitz W, Wendt G (2004) Appl Catal B 52:135-143

39. Carno J, Ferrandon M, Bjornbom E, Jaras S (1997) Appl Catal A 155:265-281

40. Tang X, Chen J, Huang X, Xu Y, Shen W (2008) Appl Catal B 81:115-121

41. Ayastuy JL, González-Marcos M, González-Velazco J, Gutiérrez-Ortiz M (2007) Appl Catal B 70:532-541

42. O’Malley A, Hodnett B (1999) Catal Today 54:31-38

43. Agüero F, Barbero B, Pereira M, Figueiredo J, Cadus L (2009) Ind Eng Chem Res 48:2795-2800

44. Lamaita L, Peluso MA, Sambeth JE, Thomas HJ (2005) Appl Catal B 61:114-119

45. Suib SL (2008) J Mater Chem 18:1623-1631

46. Peluso MA, Sambeth JE, Thomas HJ (2003) React Kinet Catal Lett 80:241-248

47. Peluso MA, Gambaro L, Pronsato E, Gazzoli D, Thomas HJ, Sambeth JE (2008) Catal Today 133:487-492

48. Sanz O, Delgado J, Navarro P, Arzamendi G, Gandía L, Montes M (2011) Appl Catal B 110:231-237

49. Li T, Lei Y, He Y, Teng B, Luo M, Zhao L (2011) Reac Kinet Mech Cat 103:419-429

50. Santos V, Pereira M, Orfao J, Figueiredo J (2001) J Hazard Mater 185:1236-1240

51. Agüero F, Barbero B, Gambaro L, Cadus L (2009) Appl Catal B 91:108-112

52. Bielanski A, Haber J (1990) Oxygen in catalysis, vol 43. Marcel Dekker, New York

53. Witko M, Haber J, Tokarz R (1993) J Mol Catal 82:457-466

54. Irigoyen B, Juan A, Larrondo S, Amadeo N (2001) J Catal 201:169-182 